\title{
Students' views on database management systems course designed according to problem-based learning
}

\author{
Adem Uzun', Ahmet Onur ${ }^{2}$, Sercan Alabay ${ }^{3}$ \\ ${ }^{1}$ Computer Education and Instructional Technologies Department, Faculty of Education, \\ Bursa Uludag University, Turkey \\ ${ }^{2}$ Software Development Department, Zurich Sigorta, Turkey \\ ${ }^{3}$ Foreign Languages School, Galatasaray University, Turkey
}

\begin{tabular}{l}
\hline \hline Article Info \\
\hline Article history: \\
Received Jan 6, 2020 \\
Revised Feb 26, 2020 \\
Accepted Feb 29, 2020 \\
\end{tabular}

Keywords:

Database management systems Problem-based learning Student views

\begin{abstract}
The aim of this study was to design a learning environment supported by a problem-based learning method and to obtain students' views on this process. In this context, the Database Management Systems course was taught according to the problem-based learning method. The participants of the study consisted of 25 students from the 2nd-grade students studying in the Department of Computer Education and Instructional Technology in the spring semester of 2015 at Uludag University Faculty of Education. The research design of this study was the case study, which is one of the qualitative research designs. Data were obtained from the students via a semi-structured interview form. Descriptive analysis was applied to the data obtained from the interview. According to the results obtained from the analysis of the data, the students were generally satisfied with the problem-based learning practices. In addition, the students emphasized that it is important to have a sufficient level of necessary knowledge of the implementation of problem-based learning to design the classroom environment.
\end{abstract}

This is an open access article under the CC BY-SA license.

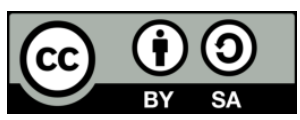

\section{Corresponding Author:}

Adem Uzun,

Computer Education and Instructional Technologies Department,

Bursa Uludag University

16159 Gorukle Kampusu Nilufer, Turkey

Email: auzun@uludag.edu.tr

\section{INTRODUCTION}

In recent years, the development of technology has led to significant changes in human life. Similar changes have also taken place, particularly in the field of education. Although technology is used as a tool in the lessons, it has also reached the point of being the subject of instruction [1]. After technology affects human life so much, societies are forced to continue their lives by integrating it with the developing technology and the big information world that emerged. In order to achieve this integration and to keep up with time, the necessary knowledge and skills are tried to be obtained through educational institutions [2]. There is a need to include new technologies in the education process in order to increase the quality in education. It is important that students are educated to be individuals who keep up with the changing and developing technology, and who research, question and take an active role in the learning process, and contribute to the society they live in by having an effective attitude towards technology. In this context, new methods and approaches should be applied in the education system. Students should actively participate in learning activities for more effective and permanent learning, work in collaboration to develop individual 
learning skills, provide self-motivation and organize activities for this purpose [3]. It is not possible that this new understanding, which aims to make the students more active and increase the motivation in the lessons with the fundamental changes and developing information technologies, cannot be applied with the methods that traditional teaching provides [4].

Recently in the field of education, it was observed that constructivism as a learning approach is preferred because it supports the active participation of students [5]. Although the constructivist approach was introduced by Bruner in the 1960s, the basis of this approach dates back to the 18th-century philosopher Giambattista Vico. Therefore, it has an impact in many areas from philosophy to mathematics, from sociology to architecture [6, 7]. The constructivist approach is a student-centered approach, in which the learner constructs knowledge through the acquisition of objects and concepts from the outside world and the use of old experiences. In the learning process, information is effectively structured by student's mind [8]. The constructivist approach forces teachers and students to think about the subject and to investigate it. Thus, the way to make learning permanent is actualized [9]. The constructivist teacher should not only provide the students with the objectives of the course but also confront them with the problems and real-life complexities chosen from daily life. In this way, students can construct the information they learn from daily life examples for the future [6].

Researchers have made some definitions of problem-based learning. According to Krynock and Robb [10], problem-based learning is actually constructivism itself. According to Savery [11], problem-based learning is an approach where students produce ideas and solutions throughout the process as much as possible, determining what they know or not, and starting the presentation of the problem, rather than reading and being explained the specific purposes. According to Putnam [12], problem-based learning is an instructional approach that reveals students' problem-solving skills and also uses real-life problems to teach them the necessary knowledge and concepts related to the course. The problem-based learning is an approach that helps students who face real-life problems take responsibility and contribute to their experience [13-15].

When the literature is examined, it is seen that many studies related to problem-based learning are conducted, these studies are related to social sciences and science, they examine the variables of achievement, motivation and goals and also they are carried out with different age groups [16-20]. However, most of these studies are quantitative studies comparing problem-based learning with direct instruction. In addition, the studies carried out using the problem-based learning approach about Database Management Systems (DBMS) course are quite limited. DBMS is a practical course and students taking this course must acquire and demonstrate a range of skills, such as problem solving, communication and interpersonal relationships, in order to be ready for their professional life. All these skills can be developed with a problem-based learning approach. This is the reason for choosing that approach for this course [21]. The main problem of this study is to reveal the important components that will be required in the design of an applied IT-based course such as DBMS, according to the problem-based learning approach. Because the most important feature of qualitative studies is to obtain in-depth information on the subject studied. [22]. In this study, the important components to be considered in the instructional design for DBMS course will be examined in depth in accordance with the student experiences and opinions. In this context, the contribution of this study is that it is a qualitative study and carried out with a naturalistic inquiry approach, contrary to the similar studies in the literature. Therefore the aim of the study is to find out the important components of designing a problem-based learning environment for DBMS course.

\section{RESEARCH METHOD}

\subsection{Research design}

In this study, the naturalistic inquiry approach was preferred which is an approach in which people and groups' experiences and actions are defined, observed or interpreted [22]. The case study method was used as the research design. Case study research is a qualitative approach in which the researcher investigates a confined system (a case) or multiple confined systems (cases) through time, through detailed, in-depth data collection, which includes many sources of information, such as observations, interviews, audiovisual material [22-25].

\subsection{Participants}

The participants of the study consisted of 2nd-grade students studying in the department of Computer Education and Instructional Technology in Uludag University, Faculty of Education in the spring 2015. Although there were 78 students taking the Database Management Systems course some of the students did not participate whole lessons. In total, 25 students participated to the learning process and 10 of them were interviewed. 


\subsection{Data collection tool}

Since this study was a qualitative study, the number of participants is limited and a standard measurement tool was not used. Therefore, in order to obtain reliability and validity of the study, the data triangulation was used. According to Yıldırım and Şimşek [23], collecting data with more than one way in the same research contribute to increasing the validity and reliability of the data. In this respect, observation of students' behaviors in whole learning process and their responces to the interviews were used in the data collection.

The developed Semi-Structured Interview Form was used at the end of the course in order to obtain the students' views about the Database Management Systems course which was carried out according to the problem-based learning method. This form was developed by the researcher by taking the opinions of 2 experts who have 10 and 15 years of experience in the field of instructional technologies. The interview technique has advantages such as time flexibility, observation of non-verbal behaviors and high response rate [23]. While preparing the interview form, the possible questions obtained from the literature were determined and it was paid attention that the questions were open-ended and non-directive to serve the research problem.

\subsection{Implementation phase of the research}

The implementation started in the last week of April and completed in the first week of May. Table 1 shows the dates of the implementation of the research.

Table 1 The implementation plan of the research

\begin{tabular}{ll}
\hline Implementation Phase & Date \\
\hline Determination of pre-knowledge status & 9 April 2015 \\
$\begin{array}{l}\text { Creating groups } \\
\text { Informing students about problem-based learning } \\
\text { method }\end{array}$ & 30 April 2015 \\
$\begin{array}{l}\text { Giving Scenario 1 (Book List) to Students in the } \\
\text { First Session }\end{array}$ & 30 April 2015 \\
$\begin{array}{l}\text { Giving Scenario 2 (E-commerce database design } \\
\text { and creation) to students in the Second Session }\end{array}$ & 7 May 2015 \\
$\begin{array}{l}\text { Conducting interviews with students } \\
\text { 11-15 May 2015 }\end{array}$ \\
\hline
\end{tabular}

As the number of students taking the course is 78 , the Database Management Systems course is divided into A group (40 people) and B group ( 38 people) for each student to have a computer considering the laboratory capacity. Group A takes the course in the morning and Group B takes the course in the afternoon. Problem-based learning practices are also handled in this way.

Prior to the application, the pre-knowledge levels of the students were determined by the instructor and the researcher. Prior knowledge levels were determined as no, low, medium and high pre-knowledge. Taking this pre-knowledge into consideration, the groups were formed in a homogeneous way with students from all levels. Group A students were divided into groups of 5 before starting problem-based learning practices. A total of 8 groups were formed. Group B students consist of 8 groups; 6 of which consist of 5 people and 2 of which consist of 4 people. The seating order of each group was determined by the researcher in order to observe the physical condition of the laboratory in which the course will be taught and. Groups were named as Group 1, Group 2, Group 3, Group 4, Group 5, Group 6, Group 7 and Group 8. The course was conducted by the researcher and the instructor responsible for the course was present in the classroom to assist the observation.

In the first week sessions, students were given detailed information about the problem-based learning model and their questions were answered. Then, the groups were announced to the students, however, as some groups included students who did not attend the class, the students whose peers did not come were transferred to the other groups by keeping the pre-knowledge levels to maintain homogeneity of the groups. In this case, Group A (morning group) fell from 8 groups to 7 groups, and Group B (afternoon group) fell from 8 groups to 5 groups. After these arrangements, everyone took their place in the laboratory with the group members in the determined seating arrangement. The groups were then asked to download the activity form which was uploaded to the web site by the researcher before the application and which was required to be completed during the first-week session and the list of books needed in the framework of scenario 1 from the web site. After the students completed the download process, scenario 1 was distributed to all groups. The students were asked to read and understand the scenario thoroughly, to determine the problem situation and to express the problem in their own sentences, then to form an appropriate task distribution within the group and to determine a suitable strategy. As it was requested to design tables on 
Excel program in the scenario, students were expected to choose problem-solving strategies such as making tables and using old knowledge. During this period, the researchers avoided answering students' questions clearly. The students produced various solutions based on what was given in the scenario on an Excel sheet in a group. Then, with the guidance of the researcher, they were asked to compare the relational designs they created with the original form of the book list. At this point, they were asked to compare the number of characters between 2 documents. Comparing with the solutions of the other groups, the groups reported their solutions and their results to the activity forms. These forms and the relational table designs they created were sent to the researcher by e-mail for the purpose of examining, and they were used to increase the validity of the observation data.

In the second week of the session, the second topic, database design, and creation scenario, was applied in accordance with the problem-based learning model. Some of the students who attended the first session has not attended the second session, and some students who did not attend the first session also came to the second session. It was ensured that the students who came to the first session were in the same group in the second session, new homogeneous groups were formed by performing the necessary transfers between the missing group members. Students who came to the second session for the first time were not included in the observation. In this case, in the second week, group A consists of a total of 5 groups and group B consists of a total of 3 groups. After the necessary arrangements were made, the students were asked the difficulties they faced in the first session and solutions were produced in order to avoid the same difficulties in the second session and individual deficiencies were asked to be completed at the beginning of the session. The groups were then asked to download the activity form, which was uploaded by the researcher to the web site before the application, which had to be completed during the first-week session, and scenario 2 was distributed to all groups as a printout. The students were asked to read and understand the scenario thoroughly, to determine the problem situation in the scenario and to express the problem in their own sentences, then to form an appropriate task distribution within the group and to determine a suitable strategy. Since it is possible to create a table and write an query via the diagram in Microsoft SQL Server Management Studio, students are expected to choose problem-solving strategies in this direction. With the experience of the first week, the students created the required table designs as a group. After the warnings of the researcher, some wrong designs were corrected by the groups and turned into more appropriate ways. At the end of the session, the students were asked to e-mail their databases, queries they wrote and the activity forms they completed after the remaining stages of the scenario which was prepared in accordance with the course's outcomes. At the end of the session, brief opinions and evaluations were taken from the groups, each group talked about their research and thus all groups were given the opportunity to learn what the others thought and did. When the session ended, the names of the students who accepted to participate in the interview were noted by the researcher.

During these sessions, student-student and teacher-student relationships in the problem-based learning process, which problem-solving steps the students used and their behaviors in group work were observed. Observations were recorded by the researcher. Observation is also supported by audio recording in cases where it is difficult to take notes. Interview technique was also used in order to interpret the data obtained from observation data more accurately. The individuals to be interviewed were determined on a voluntary basis. In this context, a total of 10 students were interviewed. During the interviews, audio recordings were made with the permission of the students. Each interview lasted an average of 15-20 minutes. Interviews were conducted in a quiet classroom environment.

\subsection{Data analysis}

The data were examined according to the themes and sub-themes. Descriptive analysis was applied to these themes and sub-themes with the appropriate code list. The aim of the descriptive analysis is to present the findings obtained from the research to the reader by arranging and interpreting them. In this context, direct quotations can often be included to reflect the views of the interviewees in a striking manner [23].

\section{RESULTS AND DISCUSSION}

The interviews were conducted with 10 students who participated in the database management systems course, which was processed according to the problem-based learning model, during the 2 sessions. For this purpose, a semi-structured interview form consisting of 7 questions was applied to the students. The students participating in the interview were selected on a voluntary basis and audio recordings were made with the permission of the students during the interviews. The themes of interview analysis were determined with the help of interview questions and data obtained from the literature. The themes and subthemes used in the analysis of interview data are presented in Table 2. 
In the analysis of interview data, the student is expressed in abbreviations. The general purpose of asking these questions is to provide an in-depth understanding of students' views on problem-based learning practice. The first question of the interview is "What do you understand from problem-based learning when you consider the applications made, what do you think is problem-based learning?". This question was answered by IY as "I understood that there should be pre-knowledge, if there is no prior information, the student will have difficulty in understanding the problem". SK said "I understood it as a model that we combined the existing practice with pre-knowledge." by emphasizing the importance of prior knowledge in problem-based learning practices. UD said "There is a problem that occurs anywhere, we call it a problem. According to this problem, we develop the required solutions together with the group". BD said, "For example, in the first scenario, the problem was that the data took up a lot of space; I can take the problem and define it as a solution from a new perspective." CU emphasized the advantage of the problem-based learning model and expressed his satisfaction by saying "Since we learned only theory in the previous lessons, we have learned logic in these applications most importantly. In order to do this work, the logic must be very good, this model gave us this". EAK, one of the other students, described this process as "creating solutions", while FA described "a system in which the problem situation was evaluated and certain solutions were found together with the group members". MT stated that the strategies they applied during the problem-solving process contributed more to their learning by saying "The issue is explained through a problem. This enables better learning. It is ensured that the students engage in it". Finally, YT stated that he found it meaningful to have real-life examples of problem-based learning scenarios by mentioning "There is learning through narration and there is also learning in practice. It makes sense to manipulate the application by doing so. It is better and more understandable to do something with concrete and real-life data".

Table 2 The themes and sub-themes used in the analysis of interview data

\begin{tabular}{ll}
\hline Themes & Sub-themes \\
\hline Properties of the Problem & Attractive \\
& Interesting \\
& Convincing \\
& Adequacy of data \\
\hline Group Work & Distribution of tasks \\
& Group Communication \\
& Seating arrangement \\
\hline The solution to the Problem & Identifying the Problem \\
& Creating a Solution Plan \\
& Strategy Implementation \\
\hline Use of Resource & Asking the Researcher \\
& Research from the Net \\
\hline Comparing with Traditional Methods & Course Aspects \\
& In terms of the classroom environment \\
\hline Evaluation & Positive \\
& Negative \\
\hline Suggestions & Course-oriented \\
& Problem-oriented \\
\hline
\end{tabular}

The second question of the interview is "How did you solve the problem?" All participants stated that they solved by interacting within the group and brainstorming. However, IY replied "Usually, I made the association, other friends helped me" and emphasized he behaved as a leader in the group. This response of IY also coincides with observation data. In addition to this question, some sub-questions were asked. The first sub-question of the second question is "What did you think during the process?" EA answered "It was a reminder and refresher for me because it was something I knew before. I had knowledge before, but I forgot, for example, it was a reminder". SK referred to the contribution of group work to the process by saying "We tried to find a shorter and easier way and do it that way. It already comes to mind when you talk to the group". UD stated that they focused on the problem by saying "During the process, we have based the problem, we have thought about the solutions for the problem because our main starting point is the problem, how can we solve it, how we can develop solutions to it". EAK replied, "I thought about how I can apply this in my life or how this will come up to me, or how I can use it in my business life, and when I think about it in economic terms, what kind of job will it provide me". Likewise, FA said " We thought where and how this would help us. I thought about how to use it in real life. Thinking of these, we created the solution". The responses of EAK and FA are strong examples that scenarios used in the problem-based learning process are likely to face in real life. MT said he was thinking of alternative ways to solve 
the problems by saying "I thought about how to solve the problem at that moment". YT said, "First of all, we imagined this scenario. We took the necessary steps into consideration by thinking about the needs and capacity of this scenario". The second sub-question of the second question is "When did you need a teacher?" Students who were not accustomed to problem-based learning tended to ask some questions about the practice at the beginning of the application. In addition, they generally needed teachers in situations where they were stuck in producing solutions when they were not sure of the results obtained, and in technical error/warning situations given by computer programs. Nevertheless, there are also those who state that they do not need teachers at all. For example, EA stated that "I didn't need a teacher in the lesson process, I just needed to understand the problem, I thought I could do it if I understood the question ". The third sub-question of the second question is "Which sources did you use?" All participants stated that they applied to their old information. In addition, there were students who did research on the internet. For example, EA stated that "I think it was the second scenario if I remember correctly, we looked at a certainplace on the internet". IY answered, "We used our previous knowledge and did some research on the internet". BH mentioned they did not use any resource "No, we didn't take advantage of anything, we only made decisions by putting forward ideas with friends." The fourth sub-question of the second question was "What data/information did you refer to in the problem statements to reach the result? Did you think that was enough?" All participants answered this question as it was sufficient generally. In addition, it has been stated that they had difficulty in understanding some points from time to time. EAK stated that he had difficulty because he was not used to problem-based learning by saying "For people like me who took this course for the first time, the scenario might have been a bit narrow, of course, it would have been nice if it had been a bit more descriptive. However, I overcame it with the support of my friends and the guidance of the teacher. But now, with these practices, everything was shaped in my head, and I wouldn't be stranger if I came across it another time".

The third question of the interview is "What are your views on the problems in the courses you are studying according to the problem-based learning model? EA emphasized a memorable feature of visual materials by saying "Problems could be given visually in the form of video, not as an extra text, and extra required data could be given in the printed form". IY expressed positive opinions by saying "I was intrigued, this may happen to us. When we are appointed as a teacher, there will be such problems in the school and there will be some points that we need to know about database relations. Again for scenario 2, if we work in a private company, we may be asked to create and associate databases. Things that are related to real-life". SK "I haven't seen a database lesson in high school, these problems were good for understanding the logic of the job. We have seen that there can be many ways, not away, it was good to understand this logic. Ir From this point of view, it is possible to say that the problems used in scenarios have the characteristics of poorly structured problems. UD We've seen a relational database before, but it's hard to keep in mind because of the lack of implementation. Particularly in scenario 2, we learned the importance of relational database design when creating a database in case of working in a private company. Thus started positive feedback. BH Until I saw the scenarios, I didn't think data repetition was a problem. We are accustomed to writing in Excel in the normal way, but after seeing the applications, I always try, even if I can't, I 'll keep trying. FA "In fact, the problems are very realistic, for example in the first application; a school is newly opened and does not have a library, then the library is set up and books come, so a list must be kept. In the past, this was performed manually with pen and paper in schools, but now it is necessary to have a proper computer system. " MT and YT also emphasized the real-life examples and stated that the problems in the scenarios are the kind of problems that may be faced in the future and expressed a positive opinion. These statements prove that the problem situations in the scenarios consist of the situations that the students may encounter in real life. In addition to the third question of the interview, sub-questions were also asked. The first subquestion of the third question is How interested are you in the problem?. All the students stated that they found the problems extremely interesting. The second sub-question of the third question is, ne How convincing did the scenarios you read compare to real-life?. All participants stated that they found the scenarios convincing. The third sub-question of the third question is hangi What alternative solutions came to mind when you read the scenarios?.. EA I have partially reached the solution, so I didn't want to ponder further because I thought I was doing it, so I didn't look for an alternative solution.This situation can be interpreted as the students are accustomed to teaching with the traditional approach and lack of reflexes to develop different hypotheses and solutions. IY "There were alternative solutions, there were friends who made 4 different tables and there were 3 different tables. There are different solutions. " SK said, instead of designing tables directly in Excel, I thought of creating them in SQL Server. Thus, it can be said that this student has determined different alternative ways about the method. UD Each programmer's head works separately. He can think of separate things. When we look at the problem, we design things for it, but we meet a certain standard. If I want to be more useful, for example, if I want to keep statistics, I can keep it on another table. There were alternative ways for individual use. In that way, he emphasized that alternative 
ways of solving the problem could be produced. "If I could sit at home and think alone, I would have found alternative solutions," BH said, referring to time constraints. CU, I thought of two ways, after all, considering the example in scenario 1, you won't be permanent in that school. I thought that the system we were going to do should actually appeal to the general and it was supposed to be concise. Today, you can set up a simple database system for the students, but if you are today, you should leave a system that you can understand when someone else comes to you tomorrow. Ederek EAK and MT stated that they were not considering any alternative solutions. FA In the first week there were lots of alternative ideas, in the second week the same ideas were generally put forward. But in the first week, 2-3 different people in the group expressed different ideas. Erek emphasized the importance of the scenario in generating alternative ideas. YT said, da For example, in the first scenario, I thought why it was just the library or the library of that school. I thought of alternative solutions that might have been a situation where all the library data in the surrounding area could be shared. For example, the data of the Ministry of Education could keep all the libraries in Turkey. "Specifying the form of an opinion, the structure obtained in a wider range stated may also be used in another alternative.

The fourth question of the interview was What do they think about the group work. EA "I think the number of people in the group work is high. Normally there were groups of 5 people, I think even 3 people is not good.. It seems to me that 2 is more appropriate. "IY "It was better to have group work. The process becomes easier when you help with group friends. Rather than doing it alone, many different people in the group are united and one does not know the other and therefore the problem is understood." SK said, the people in the group who were not good at Microsoft Excel, benefited from the program. UD says group work is very useful because the thought of one person and three other is not the same which means there are three different perspectives, ready to discuss and to come up with a new idea. In that way, more effective ideas can be presented to reach a solution. Based on these statements, it can be said that the problem-based learning environment provides an opportunity for students with poor prior knowledge to develop their social skills and responsibilities. Finally, YT said, "The groups were a bit crowded, 3 people could be enough, but 5 people were a bit crowded. As a result, when 5 people sit in front of a computer, 1-2 people can stay out. But I understand that this is due to the lack of laboratory". He pointed out a large number of people in the group.

The first sub-question of the fourth question was "How did the task distribution within the group occur?". The purpose of asking this question is to determine the factors affecting the formation of roles within the group. EA said, "At that moment, we said to those who know little in the group, we know better, we do the theoretical part and you follow. We said that you would do the part of the writing to be sharing tasks, we would have synchronized. In other words, we tried to get everyone involved at the end. " IY "Friends with pre-knowledge were more prominent, others were assisting". "There was one volunteer for writing, others preferred to comment," SK said. UD said, "The distribution of tasks was as follows: One member read aloud to help, the other gave supportive ideas and the last member criticized for giving supportive ideas. A product emerged from the combination of these. BH said, "A member was in charge of computational tasks. The rest produced ideas and came to conclusions with common ideas". YT explained the task distribution as follows: "Everybody tried to solve the logic after reading the script, and the process developed by adding something from the first to the last reader. 1 person entered the data continuously, as we enter the data each time we re-read the scenario and completed the deficiencies, so that was our distribution of tasks". The general view obtained from these statements is that the distribution of tasks within the group is based on the pre-knowledge and skills of the individuals. People have chosen the task they think they can do well and have contributed to the group accordingly. In addition, some participants concluded that they agreed in a common way and completed the process in a democratic way.

The second sub-question of the fourth question is " What are your views on intra-group communication?". Looking at the answers given to this question, all students said that communication was good and that there was no problem. In addition, it was stated that after the problem-based learning practices, the communication between some of the friends in the group was strengthened. For example, EAK stated that "It was good work, the distance between you and the other person is decreasing. Thanks to this study, we have got closer a little with a friend who I did not communicate with before". Therefore, it can be said that these practices contribute positively to the social skills of the people. The third sub-question of the fourth question is "What do you think about the seating arrangement in the classroom?. Most of the participants expressed a positive opinion about the seating arrangement. However, some have stated that there are some problems caused by the number of people. EK said, "I think the groups were the closest to perfect in that laboratory setting". IY The seating arrangement was beautiful, the groups were separated and there was no problem. IY SK "When 4 people are in front of a computer, it can be a problem. I sometimes couldn't see the screen. Terek, emphasizing a large number of people in the group. UD "I think about the seating arrangement: For example, group 1 was sitting in one place, group 3 was sitting in another place, the groups 
were not close to each other. It was good to have such a seating arrangement because everyone would produce unique ideas. EAK mentioned "There was a problem with sitting stemming from lab. It could be a little more organized". FA expressed positive views by saying "Because it was a group work, each group sat separately, everyone sat on one computer, so because we were a group, there was only one product, which was nice. ". MT also said, "I think the seating arrangement was good, there was no problem". The fourth subquestion of the fourth question is "Imagine that you are practicing without a group, what positive/negative things would happen?". EA mentioned he wouldn't do tasks alone by saying "If I were alone, I wouldn't be able to make them realistic. I needed a teacher or another friend. IY preferred to work with a group by saying "It would be a little more time consuming if I did it alone, there would be problems. Because we did in order while doing with the group, not only one member got tired. Without task sharing, everything would be more tiring and time consuming on one person's shoulders". Other participants made similar statements about this question.

The fifth question of the interview is "What do you say if you compare the lessons we have studied according to the problem-based learning model compared to the previous weeks?". IY said "According to the problem-based learning model, the lesson we studied was a little better, it seemed remarkable to me. Everyone was trying to do the application itself after the course was told. In a way, even if there is no pre-knowledge, the course cannot be processed according to the problem-based learning model. It is better to use this model after learning something. If it is more compact, it can be, for example, up to mid-terms, normally after mid-terms, with problem-based learning activities and scenarios. Without pre-knowledge, it is impossible". SK said "It's good to practice. If the teacher gives the course continuously, it can be boring". UD argued that there should be a pre-knowledge about the subject to be covered. He said "Compared to the previous lessons, there was a scenario in these practices and the teacher was a little bit passive. Our teacher told us in advance and then made us do it, did not refer to a specific source or something. Since the pre-knowledge is also used in these applications, we actually used the information we learned in the previous lessons in this application process. So we were able to make the application already. For example, if these scenarios were implemented at the beginning of the semester, most people would not. There should be a pre-knowledge". BH said "I prefer group work. When it comes to group work, it is efficient for both the student and the teacher. Sometimes you can't do it alone, it happens to me occasionally. As a group, we can reach a solution more easily. And when you have group work, motivation is better, you try to concentrate more. If a person is doing something and you don't, then the group breaks up. That's why he's trying to keep his concentration. You are motivated". FA mentioned "There was a lecture and then a few exercises, but in these two weeks we do everything ourselves. It was more comfortable as a group, it was easier when everyone said something. When the lecture is given normally, the teacher tells you something when you take notes, then it is likely to miss what he says. In our group work practices, 2-3 people were thinking about the problem situation and 1 person followed the instructor's explanations. According to the problem-based learning model, we understood the lesson a little better. You are more susceptible to the issue when you start to work yourself". MT said "Lessons in this application period were more productive, some more participation was achieved. The students were more active."

The sixth question of the interview was "Is there any negativity that you have experienced during the DBMS courses that are based on the problem-based learning model? If so, what are they?". Findings from the answers given to this question show that students did not experience any negativity in the lessons taught according to the problem-based learning model. Only YT said "There is a lack arising from our laboratory, regarding the seating arrangement. I didn't see any negativity except it. It was good". It can be said that this negativity is caused by the physical conditions of the laboratory."Is there anything else you want to say?" is the seventh question of the interview. This question was asked in order to obtain the students' other thoughts about the process other than the questions asked. UD expressed his ideas by saying "I want to say, it may be easier for us to relate topics such as the relational database with real-life examples. It can be applied in different subjects. However, examples need to be open to scripting. For example, there are some issues that would be easier to teach in the traditional way, otherwise, it would be nice to deploy the scenario method". $\mathrm{BH}$ pointed out that the number of people in the group should be regulated by saying "I think the number of groups should not exceed 3 people according to that laboratory. The screen of the computer sometimes cannot be seen. If there was a normal classroom layout, 4-5 people would be normal, but we should not exceed 3 people in our laboratory. The groups should be organized a little". CU expressed his satisfaction with the implications "I can say that these two applications are useful". EAK expressed his satisfaction with the problem-based learning practices by saying, "It is better if these implications can be made more. I think it would be better if there is a setting in which students can express themselves in such a comfortable way". PT expressed his feelings by saying "It would be good to have more of this kind of practice in the university and it would be good for the student to express his / her opinion. The idea of the teacher is good, we understand 
this but we are 50 people in the classroom, and when we meet at a common point, that course can become more active and easy to operate".

Three important issues that emerged in the light of the findings of the research presented above were discussed in the following paragraphs.

Student satisfaction was an important component of the design of a course. According to the students' responses to the interview questions, it is clear that students are generally pleased to take the DBMS course designed with the problem-based learning method. Students are generally satisfied with the problem-based learning practices and their opinions about the process are generally positive. They stated that the scenarios in this course were interesting, convincing and real life-related. They also stated that group work motivated them to learn. The students shared tasks throughout the process and the communication within the group was extremely good. The distribution of tasks were suitable for them. In addition, students think that problem-based learning practices should be applied to different courses. Similar results can be found in the literature. As an example, Demir [26] conducted a study and stated that the students reported positive opinions about the course based on the problem-based learning method. His students also think that the scenarios used in the problem-based learning process contribute positively to the learning processes. These scenarios increased his students' sense of responsibility and the learning process was fun for them. In another study conducted by Uluyol [27], students emphasized that they want to apply the problem-based learning approach in other courses. Findings about students' views on group work coincide with the findings of Biber and Başer [28] on the implementation of the problem-based learning method. Students have similar positive opinions about problem-based learning methods according to the conclusions of [29-35].

Students' responses point to another imprtant component for the Database Management Systems Course design. According to their oppinions, in order to apply the problem-based learning model, they should have a basic pre-knowledge about the subject to be studied. For example, during the interview, IY emphasized that there should be pre-knowledge by saying "....in a sense, the course cannot be taught according to the problem-based learning model if there is no pre-knowledge. It is better to use this model after learning something". Likewise, UD said "For example, if these scenarios were applied at the beginning of the term, most people would not manage. Students should have pre-knowledge" Based on this, at the beginning of the lesson, it is necessary to start with the traditional method and switch to the problembased learning method as the students' level of knowledge increases. Therefore, it is not necessary to teach the course either with only the traditional method or with the problem-based learning model.

Finally, students emphasized that in order to carry out the problem-based learning applications within the scope of the DBMS course, there should be a fully equipped computer laboratory that meets the requirements of today's digital age and has the physical conditions appropriate for the class. This result shows that technical infrastructure of the computer laboratuary is an important component of DBMS design. Findings from the interviews show that the students experienced some negativity due to the physical conditions of the laboratory and the number of students in the group.

\section{CONCLUSION}

In this study, the important components to be considered in the instructional design for DBMS course was examined in accordance with the student experiences and opinions in a problem-based learning environment. In summary, the experiences and the opinions of the students provided detailed information on 3 important components such as student satisfaction, pre-knowledge level and technical infrastructure, when problem-based teaching is used in the design of the DBMS course.

\section{ACKNOWLEDGEMENTS}

This article is adapted from Ahmet Onur's master thesis titled as "Student's Views on Database Management Systems Course Designed According to Problem-Based Learning Method: A Case of Uludag University" which was presented to Uludag University Institute of Educational Sciences.

\section{REFERENCES}

[1] S. Demir, M. F. Özmantar, E. Bingölbali, and A. Bozkurt, "Sınıf öğretmenlerinin teknoloji kullanımlarının irdelenmesi," in 5th International Computer \& Instructional Technologies Symposium, Z. Genç, Ed. Elazığ: Firat Üniversitesi, pp. 922-928, 2011.

[2] A. Adıgüzel, "İlköğretim okullarında öğretim teknolojilerinin durumu ve sınıf öğretmenlerinin bu teknolojileri kullanma düzeyleri,” Dicle Üniversitesi Ziya Gökalp Eğitim Fakültesi Dergisi, vol. 15, pp.1-17, 2010. 
[3] F. Gürsul, "Çevrimiçi ve yüzyüze problem tabanlı öğrenme yaklaşımlarının öğrencilerin başarılarına ve matematiğe yönelik tutumlarına etkisi,” Ph.D. dissertation, Ankara Üniversitesi Eğitim Bilimleri Enstitüsü, Ankara, Türkiye, 2008.

[4] D.H. Jonassen and L.R. Murphy, "Activity theory as a framework for designing constructivist learning environments," Educational Technology Research and Development, vol. 47, no. 1, pp. 61-79, 1999.

[5] B. Bayrak, "Web ortamında problem tabanlı öğretim ile desteklenmiş fen ve teknoloji öğretiminin 8. Sınıf öğrencilerinin akademik başarı kavramsal anlama ve bilimsel süreç becerileri üzerinde etkisi: asit baz konusu," Ph.D. dissertation, Marmara Üniversitesi Eğitim Bilimleri Enstitüsü, İstanbul, Türkiye, 2011.

[6] A. Lortoğlu, "Sınıf öğretmenlerinin yapılandırmacı öğretim programı kapsamında eğitim teknolojisi uygulamalarında karşılaştıkları güçlükler,” M.S. thesis, Selçuk Üniversitesi Sosyal Bilimleri Enstitüsü, Konya, Türkiye, 2008.

[7] N. Şimşek, "Yapılandırmacı ögrenme ve ögretime eleştirel yaklaşım," Eğitim Bilimleri ve Uygulama, vol. 3, no. 5, pp. 115-139, 2004.

[8] D. Deryakulu, "Yapıcı öğrenme," in Sinıfta demokrasi, Ali Şimşek, Ed. Ankara, Türkiye: Eğitimsen Yayınları, pp. 53-77, 2000.

[9] J. G.Brooks and B. G. Brooks In search of understanding: The case for constructivist classrooms. Alexandria, VA: Association for Supervision and Curriculum Development, 1999.

[10] K. Krynock and L. Robb, "Problem solved: How to coach cognition," Educational leadership, vol. 57 no. 3 , pp. 29-32, 1999.

[11] J. R. Savery "Problem-based approach to instruction," in Instructional-Design theories and models, Reigeluth, C.M. \& Carr-Chellmani Eds, New York: Routledge, pp. 143-165, 2009.

[12] A. R. Putnam, "Problem-based teaching and learning in technology education," presented at the 75th , Annual Conference of the Association for Career and Technical Education, New Orleans, LA, December, 2001.

[13] C. E. Hmelo-Silver, "Problem-based learning: What and how do students learn?," Educational psychology review, vol. 16, no. 3, pp. 235-266, 2004.

[14] G. Shimic and A. Jevremovic, "Problem-based learning in formal and informal learning environments," Interactive Learning Environments, vol. 20, no. 4, pp. 351-367, 2012.

[15] H. Deveci, "Sosyal bilgiler dersinde probleme dayalı öğrenmenin öğrencilerin derse ilişkin tutumlarına akademik başarılarına ve hatırlama düzeylerine etkisi," Ph.D. dissertation, Anadolu Üniversitesi Eğitim Bilimleri Enstitüsü, Eskişehir, Türkiye, 2002.

[16] B. D. Permatasari, Gunarhadi and Riyadi, "The influence of problem based learning towards social science learning outcomes viewed from learning interest," International Journal of Evaluation and Research in Education, vol. 8, no. 1, pp. 39-46, 2019.

[17] E. Ediansyah, D. A. Kurniawan, R. Perdana, S. Salamah, "Using problem-based learning in college: Mastery concepts subject statistical research and motivation," International Journal of Evaluation and Research in Education, vol. 8, no. 3, pp. 446-454, 2019.

[18] A. Matawali, S. N. S. Bakri, N. R. Jumat, I. H. Ismail, S. E. Arshad, W. A. Din, "The preliminary study on inverted problem-based learning in biology among science foundation students," International Journal of Evaluation and Research in Education, vol. 8, no. 4, pp. 713-718, 2019.

[19] W. Malmia, S.H. Makatita, S. Lisaholit, A. Azwan, I. Magfirah, H. Tinggapi \& B. Umanailo, "Problem-based learning as an effort to improve student learning outcomes." Int. J. Sci. Technol. Res, vol 8, no. 9, pp. 1140-1143, 2019.

[20] N. H. Jabarullah, and H. I. Hussain, "The effectiveness of problem-based learning in technical and vocational education in Malaysia," Education+ Training, vol 61, no. 5, pp. 552-567, 2019.

[21] M.J. de Scheepers, R. Barnes, M. Clements and A.J. Stubbs, "Preparing future-ready graduates through experiential entrepreneurship," Education+ Training, vol. 60 no. 4, pp. 303-317, 2018.

[22] J. W. Creswell, Research design: Qualitative, quantitative, and mixed methods approaches. Thousand Oaks, CA: Sage Publications, 2017.

[23] A. Yıldırım, and H. Şimşek, Nitel araştırma yöntemleri. Ankara: Seçkin Yayıncılık, 2018.

[24] R. E. Stake, The art of case study research. Thousand Oaks, CA: Sage, 1995.

[25] R. K. Yin, Case study research and applications: Design and methods. Thousand Oaks, CA: Sage publications, 2017.

[26] B. Demir, "Probleme dayalı öğrenme modelinin nümerik analiz dersinde uygulanması," M.S. thesis, Balıkesir Üniversitesi Fen Bilimleri Enstitüsü, Balıkesir, Türkiye, 2011.

[27] Ç. Uluyol, "Problem temelli öğrenmenin öğrenci başarısına etkisi ve öğrenci görüşlerinin değerlendirilmesi," Gazi Üniversitesi Gazi Ĕ̈itim Fakültesi Dergisi, vol. 29, no. 1, pp. 19-36, 2009.

[28] M. Biber, and N. Başer, "Probleme dayalı öğrenme sürecine yönelik nitel bir değerlendirme," Hasan Ali Yücel Eğitim Fakültesi Dergisi, vol. 17, pp. 12-33, 2012.

[29] E. Özcan, "Probleme dayalı öğrenmenin fen öğretmen adaylarının problem çözme becerileri akademik başarıları ve tutumları üzerindeki etkisi,” M.S. thesis, Dokuz Eylül Üniversitesi Eğitim Bilimleri Enstitüsü, İzmir, Türkiye, 2013.

[30] P. Çetin, "İlköğretimde hayat bilgisi dersinde probleme dayalı öğrenme yöntemi uygulamalarının öğrencilerin öğrenme ürünlerine etkisi,” M.S. thesis, Dokuz Eylül Üniversitesi Eğitim Bilimleri Enstitüsü, İzmir, Türkiye, 2011.

[31] B. Günhan, and N. Başer, "Probleme dayalı öğrenmeye ilişkin öğrenci öğretmen ve öğretim üyelerinin görüșleri," Necatibey Ĕgitim Fakültesi Elektronik Fen ve Matematik Ĕgitimi Dergisi, vol. 3, no. 1, pp. 134-155, 2009. 
[32] Ş. Ulukök, "Bilgisayar destekli probleme dayalı öğrenme yönteminin öğretmen adaylarının üst düzey düşünme becerilerine etkisi," M.S. thesis, Kırıkkale Üniversitesi Fen Bilimleri Enstitüsü, Kırıkkale, Türkiye, 2012.

[33] E. İnce Aka, "Asitler ve bazlar konusunun öğretiminde kullanılan probleme dayalı öğrenme yönteminin farklı değişkenler üzerinde etkisi ve yönteme ilişkin öğrenci görüşleri,” Ph.D. dissertation, Gazi Üniversitesi Eğitim Bilimleri Enstitüsü, Ankara, Türkiye, 2012.

[34] S. Çakır, "7. Sınıf matematik dersinde çember ve daire konusunun öğretiminde probleme dayalı öğrenme yönteminin öğrencilerin motivasyonlarına ve matematik kaygı düzeylerine etkisi,” M.S. thesis, Gazi Üniversitesi Eğitim Bilimleri Enstitüsü, Ankara, Türkiye, 2015.

[35] P. Liu, "The relationship of a problem based calculus and students' views mathematical thinking. Ph.D. dissertation," Oregon State University, OR, 2003. 